\title{
Effect of Different Type of Mulching and Furrow Irrigation Methods on Maize (Zea mays L.) Yield and Water Productivity at Raya Valley, Northern Ethiopia
}

\author{
Yemane Mebrahtu $^{1 *} \quad$ Ahmmed Mehamed ${ }^{1}$ \\ 1* Department Irrigation and Drainage, Ethiopian Institute of Agricultural Research (EIAR), Mehoni \\ Agricultural Research Centre, Ethiopia \\ 1 Department Irrigation and Drainage, Ethiopian Institute of Agricultural Research (EIAR), Assosa Agricultural \\ Research Centre, Ethiopia
}

\begin{abstract}
Mulching with different irrigation practices is one of the techniques to improve soil productivity and water use efficiency. The increasing demand of water in the region highlights the need to introduce low-input and water saving technologies for agricultural sustainability and crop production, mainly in semi-arid region. The experiment was conducted at the research station of Mehoni Agricultural Research Centre (MehARC) in the Raya Valley, Northern Ethiopia, conducted during 2017-18 and aiming to evaluate the effect of mulch types on yield and water productivity, to determine the effect of furrow methods on yield and water productivity and to analyze and evaluate different techniques that enhance water productivity of maize yield. The experiment was laid out in a split plot design and consisting of three types of furrow irrigation methods (alternate, fixed and conventional furrow irrigation methods) in the main plot and two mulch types and no mulch with three replications were used as two factors to evaluate the yield and yield component including water use efficiency of maize in split-plot design. Different types of irrigation method and mulching types were significantly $(p<0.05)$ affected all the studied parameters of yield and yield components of maize at the study site. Significantly a higher maize grain yield and yield component was recorded from conventional furrow irrigation method than alternate and fixed furrow irrigation method and higher water productivity was obtained from alternate furrow irrigation method. The study area water is a limiting factor and alternate furrow irrigation method could be practiced with plastic mulch for improving maize grain yield and water productivity.
\end{abstract}

Keywords: Irrigation method, Maize, Mulching and Water Productivity.

DOI: $10.7176 / \mathrm{JBAH} / 9-20-02$

Publication date:October $31^{\text {st }} 2019$

\section{Introduction}

Agriculture is the main water-consuming sector worldwide (Biswas, 1997), which accounts 70 percent of all water withdrawn from aquifers, streams and lakes (FAO, 2011).The global expansion of irrigated areas to feed the ever-increasing population and the limited availability of irrigation water is not balanced at different part of the world. Rivers, lakes, ground water and different streams are dried due to unbalance between inflow and outflow of water in the hydrologic cycle of that particular area. In arid and semi-arid areas where moisture stress is the main challenge for crop production, the spatial and temporal variations exacerbate the problem.

Irrigation is one of the most important inputs for agricultural production. Limited water resources and increasing water demand for industrial and urban settlements have caused decreases in the quantity and quality of agricultural water use (Osman et al, 2001).

Mulching is the practice of covering the soil around plants to make conditions more favorable for growth, development and efficient crop production (Nagalakshmi et al., 2002). Mulches are used for the moderation of soil temperature, through the effects were highly variable. Colour of mulch affected soil temperatures. White (or) reflective plastic was decreased temperatures (Unger, 1984). Uses of straw and similar material mulches in different vegetable crops have greater insulating effect than pulverized soil mulch.

Mulch is a protective layer of either organic or inorganic material that is spread on the top soil to reduce the moisture loss from the soil by preventing evaporation from sunshine and desiccating winds, prevent weed growth, improve soil condition, provide home for earthworms and natural enemies found in the soil, and reduce soil compaction from the impact of heavy rains (Ramakrishna et al., 2006). Agriculture with mulch in the tropics promotes plant health and vigour. Mulching improves nutrient and water retention in the soil, encourages favorable soil microbial activity and worms, and suppresses weed growth. When properly executed, mulching can significantly improve the well-being of plants and reduce maintenance as compared to bare soil culture (Ramakrishna et al., 2006).

Organic mulches such as straw, hay, grass or leaf matter can provide multiple benefits for organic farms. They are capable of suppressing weeds, of regulating soil moisture and soil surface temperatures. They improve overall soil quality by increasing organic matter of the soil, soil porosity, and water holding capacity while also 
stimulating soil life and increasing nutrient availability (Kumar et al., 2003). Mulching is one of the good management practices among all other to improve water use efficiency. Mulching material is divided into two types, i.e. organic and inorganic material. Most frequently used inorganic mulch is plastic mulch which is effective in order to cultivate earlier produce by controlling weeds and warming the soil (Katherine et al., 2006). Application of plastic mulch increases crop yield through improving solar energy, water and fertility status of soil, reducing soil water loss and removing weeds (Bu et al., 2002). The cost of plastic mulch is lower compared with that of gravel and sandy, and it is easily managed. Thus, it has been widely reported that both the grain yield and WUE are increased under mulches (Li et al., 2001).

Covering of soil with plastic mulch, conserve soil moisture and regulate soil temperature (Zhang et al., 2005). Improvement in soil physical properties such as soil texture, porosity, infiltration rate, organic matter and soil structure have frequently been reported for soil mulched with organic materials and plastic mulch (Saroa and Lal, 2003).

The objective of the study was to evaluate the effect of mulch types on yield and water productivity, to determine the effect of furrow methods on yield and water productivity and to analyze and evaluate different techniques that enhance water productivity of maize yield.

\section{Materials and Methods}

\subsection{Description of the experimental site}

The experiment was conducted at the research station of Mehoni Agricultural Research Centre (MehARC) in the Raya Valley, Northern Ethiopia, located $668 \mathrm{Km}$ from the capital Addis Ababa and about $120 \mathrm{Km}$ south of Mekelle, the capital city of Tigray regional state. Geographically, the experimental site is located at $12^{\circ} 51^{\prime} 50^{\prime \prime}$ North Latitude and $39^{\circ} 68^{\prime} 08^{\prime \prime}$ East Longitude with an altitude of 1578 m.a.s.l. The site receives a mean annual rainfall of $300 \mathrm{~mm}$ with an average minimum and maximum temperature of 18 and $32^{\circ} \mathrm{C}$, respectively. The soil textural class of the experimental area is clay with $\mathrm{pH}$ of 7.1 to 8.1 (MehARC, 2015).

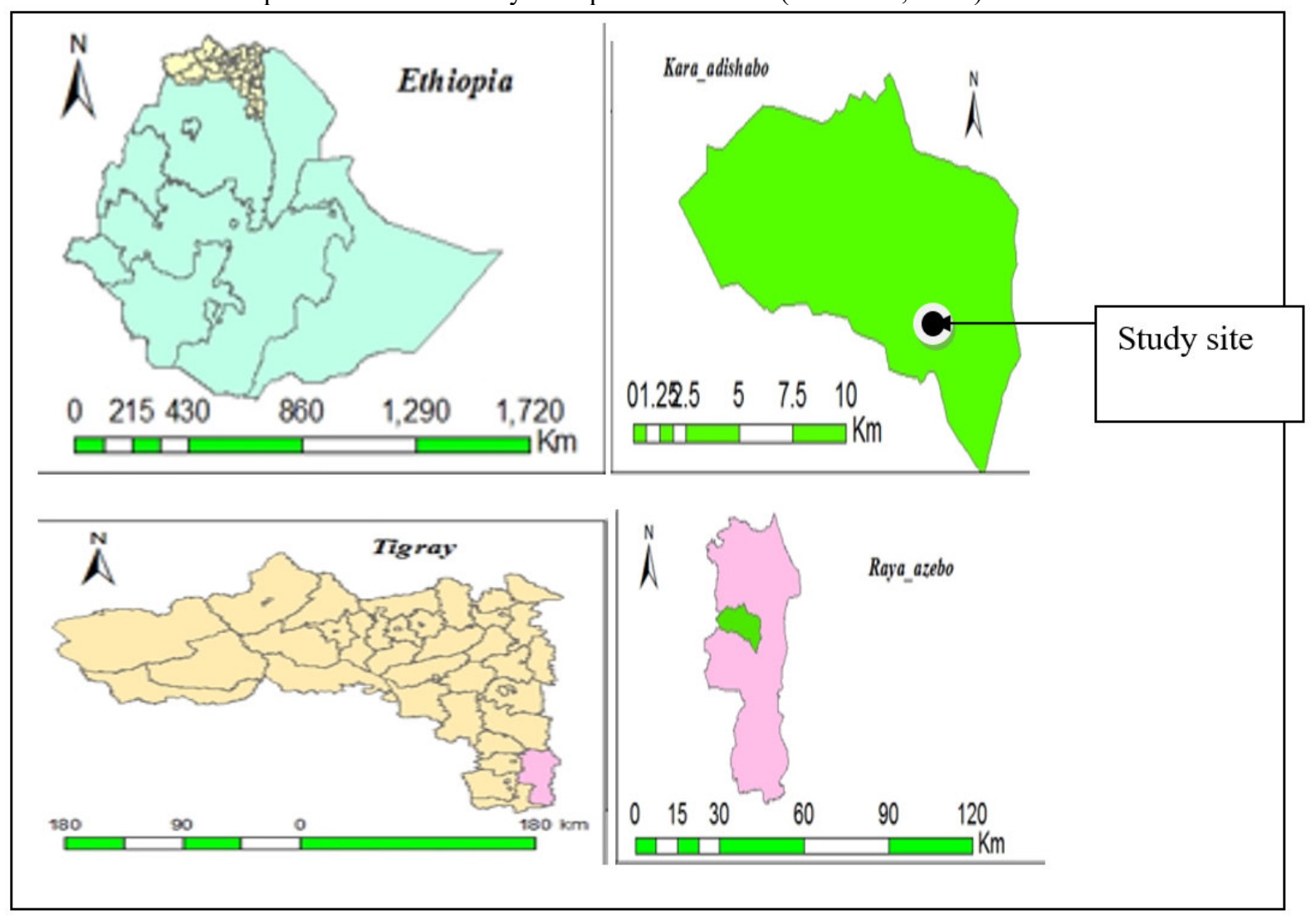

Figure 1. Map of the study area

\subsection{Climatic characteristics}

The average climatic data (Maximum and minimum temperature, relative humidity, wind speed, and sun shine hours) on monthly basis of the study area were collected from the near meteorological station. The potential evapotranspiration ETo was estimated using CROPWAT software version 8. 


\subsection{Experimental treatments}

The experiment was designed as a split plot design experiment. The treatments included three irrigation water application methods: Fixed, Alternate and Conventional, and two mulch types (straw and plastic) and control with no mulch. The treatments were randomized both at the main and sub-plot levels and assigned to plots in a split plot design and replicated three times. The furrow methods were in the main plot while mulch treatment was assigned to the sub plots. The mulching rate used 6 ton/ha straw and white plastic mulch (30 microns' thickness). Conventional furrows without mulch were considered as a control for this experiment. Each application of water was measured using a partial flume with 3-inch dimension (Table 1).

Table 1: The treatment combinations

\begin{tabular}{ll}
\hline & Treatments \\
\hline Main plots & Sub plots \\
\hline Alternate Furrow Irrigation & No mulch \\
& Straw mulch \\
\multirow{2}{*}{ Fixed Furrow Irrigation } & Plastic mulch \\
& No mulch \\
Conventional Furrow Irrigation & Straw mulch \\
& Plastic mulch \\
& No mulch \\
& Straw mulch \\
\hline
\end{tabular}

The experimental plots area, inter and intra row spacing will be determined based on the crop type. The amount of irrigation water applied will be calculated using CROP WAT 8.0 software by using necessary input data (crop, soil and long term climatic data). Irrigation water will be applied up to field capacity by monitoring soil moisture content using gravimetric method and/or using soil moisture measuring devices at different soil depth interval from the surface to the depth of maximum root zone depth depending on the crop type.

\subsection{Statistical analysis}

The collected data were analyzed using SAS 9.1 statistical software Mean separation was carried out using least significance difference (LSD) test at 5\% probability level.

\section{Results and Discussion}

\subsection{Irrigation water demand of maize}

Irrigation Water demand applied for maize throughout the growing season by the three of irrigation furrow systems was calculated. The CROPWAT model revealed that the total net of irrigation water determined in mm for each treatment (CFI, AFI and FFI) were 515.2, 274.4, and $274.40 \mathrm{~mm}$ respectively during the entire growth of the crop as it was determined from multiplication of total available water (TAW) and depletion fraction $(\mathrm{p}=55 \%)$.

The CROPWAT model revealed that the total gross irrigation water applied in $\mathrm{mm}$ to each treatment (CFI, AFI and FFI) were $858.66,457.3$, and $457.3 \mathrm{~mm}$ respectively. For conventional furrow irrigation $100 \%$ ETc was applied while for alternative and fixed furrow irrigation half of conventional furrow irrigation i.e. $50 \%$ of ETc was applied.

\subsection{Effect of furrow methods and types of mulches on growth components of maize}

\subsubsection{Plant height}

Furrow methods and mulching types was significantly influenced plant height at harvest (Table 2; Column PH). The maximum plant height was recorded from convectional furrow method $(209.1 \mathrm{~cm})$ followed by Alternative furrow method $(198.2 \mathrm{~cm})$ and whereas a minimum plant height was observed from fixed furrow method $(194.2 \mathrm{~cm})$. There was no statistically a difference showed between showed Alternative furrow method and fixed furrow method. Convectional furrow method

The effects of mulching were showed highly significant differences $(p<0.01)$ with different types of mulching. The highest plant height was observed from plastic mulch $(212.1 \mathrm{~cm})$ followed by straw mulch $(201$ $\mathrm{cm})$ and a lowest plant height were recorded from non-mulch $(184 \mathrm{~cm})$. Interaction between irrigation and mulching was not observed significant differences.

The highest plant height observed at conventional furrow had been $7.2 \%$ higher than the plant height observed at fixed furrow method. Moreover, plastic mulching improved plant height by $11.2 \%$ than no mulching condition. This might be due to highest soil moisture content in the root zone due to higher irrigation depth application in conventional furrow irrigation method than alternate and fixed furrow methods which leads might lead to moisture stress in the later cases. On the other hand, plastic mulching leads to conservation of the available soil moisture through reducing evaporation. 
This coincides with the study of Meskelu et al. (2018), Mulugeta and Kannan (2015) and Zelalem (2017) who reported conventional furrow irrigation method leads to the higher plant height followed by alternate and fixed furrow, respectively. Similar findings were also reported by Dehkordi and Farhadi (2016) and Meskelu et al. (2018) who reported that different mulching condition significantly affected plant height and higher growth of maize. Singh et al. (2016) also reported the application of rice straw mulch (6 t/ha) enhanced.

\subsubsection{Cob length}

The analysis of variance revealed that the different types of furrow methods and different types of mulch significantly $(\mathrm{p}<0.05)$ influenced parameter cob length (Table 2$)$.

The highest cob length $(16.6 \mathrm{~cm})$ was recorded at conventional furrow irrigation water application method. The maximum cob length observed at conventional furrow method was statistically superior to both alternate and fixed furrow methods. The shorter cob length $(15.1 \mathrm{~cm})$ was observed when irrigation applied using fixed furrow irrigation method.

Different studies also revealed that different mulching level affects different growth and yield components of maize. This might be mulching improve moisture content of soil through reduction of evaporation and save water in the root zone. Similar findings were reported by Awal and Khan (2000) who reported mulching improves maize growth parameters including cob diameter and length. However, the current finding is in opposing (Dehkordi N and Farhadi R 2016) who reported that different mulching condition does not affects cob length and cob diameter.

\subsubsection{Cob diameter}

Analysis of variance showed significant difference among treatments $(\mathrm{P}<0.05)$. The highest cob diameter was recorded for convectional furrow irrigation method $(4.4 \mathrm{~cm})$ followed by alternative furrow irrigation method $(4.3 \mathrm{~cm})$ while the lowest cob diameter was recorded from alternative furrow irrigation method (Table 2).

On the other hand, plastic mulch was showed the highest cob diameter $(4.6 \mathrm{~cm})$ followed by straw mulch $(4.3 \mathrm{~cm})$, whereas, non-mulch was recorded the lowest cob diameter as compare the treatments.

The increase in cob length at convectional furrow irrigation method and plastic mulch could be due to high available of soil moisture to the crop that allowed the plants to accumulate more biomass with higher capacity to convert more photosynthesis into sink resulting in higher cob diameter per plant. This result was also in conformity with those reported by (Jehan et al. 2007) and (Ali and Raouf, 2012) who concluded that increase in irrigation levels also increased ear length.

\subsubsection{Seed weight}

Data regarding 1000-grain weight of maize was showed significant differences. Maximum mean value of 1000grain weight (322.8 g) was recorded from convectional furrow irrigation method (209.1) followed by Alternative furrow method (198.2) and whereas a minimum plant height was observed from fixed furrow method $(322.8 \mathrm{~g})$ followed by alternative furrow irrigation method $(294 \mathrm{~g})$.

In the other hand the lowest mean value of 1000- grain weight $(286 \mathrm{~g} \mathrm{~g})$ was observed from fixed furrow irrigation method. There was no statistically difference $(\mathrm{P}>0.05)$ showed between alternative furrow irrigation method and fixed furrow irrigation method.

Plastic mulch has significant effect on 1000-grain weight of maize. Maximum mean value of 1000- grain weight (322 g) was observed in plastic mulch followed by straw mulch (298.8 g) and lowest value of 1000-grain weight was observed in case of non- mulching treatment (282g). Similarly, Wang et al. (2011) conducted a study to evaluate the plastic mulch along with different irrigation practices on water use efficiency, soil moisture and corn yield. Treatments consisted of plastic mulch along with furrow irrigation, sand mulch along with flood irrigation and flood irrigation without mulch. Results showed that furrow irrigation along with plastic mulch had highest grain number, grain weight per cob, and 1000-grain weight, followed by treatment sand mulching and without mulch.

\subsubsection{Grain yield}

Furrow methods showed significant effect in maize grain yield $(\mathrm{P}<0.05)$. Conventional furrow irrigation method was produced the highest grain yield with the value of 5.7 tone ha ${ }^{-1}$ followed by alternative furrow irrigation methods. In the other hand fixed furrow irrigation methods were recorded the lowest maize grain yield with the value of 4.33 tone ha ${ }^{-1}$.

Conventional furrow irrigation method was recorded $15.78 \% \%$ superior than alternative furrow irrigation method and $24.03 \%$ of fixed furrow irrigation method.

The highest grain yield of maize was recorded from plastic mulch $\left(5.27\right.$ tone ha $\left.{ }^{-1}\right)$ followed by straw mulch (5.02 tone ha ${ }^{-1}$ ). Significantly, lower grain yield of maize 4.55 tone ha- ${ }^{1}$ was recorded with non-mulch treatment.

The explanation for this reduction is that as the soil dries, the rate of absorption by roots falls, short of transpiration rate by the plant, thus creating an internal water deficit, which affects photosynthesis and reduce food production (Farooq et al., 2009). According to Pradhan et al. (2013) though crops such as wheat grain yield increase with amount of irrigation water increase, it could be grown with irrigation to replenish only $60 \%$ soil moisture depletion to field capacity to achieve higher water productivity without any significant reduction in 
crop yield. Moreover, moisture stress could be applied to enhance the utilization of scarce water in irrigation.

The current finding is in line with Meskelu et al. (2018) who reported maize grain yield was increased by $16.9 \%$ in black plastic mulch than the non-mulch condition. Moreover, Yaseen et al. (2014) revealed that maximum increase in biomass $(29.56 \%)$ and grain yield $(35.5 \%)$ were recorded on mulch and higher irrigation depth treatments. The improvement of net return of crops through maximizing yield and water productivity with limited available water by the application of mulch was also reported by Singh G et al. (2016).. The current finding is in line with Meskelu, et al. (2018).

\subsubsection{Biomass yield}

Maize biomass yield was significantly affected $(P<0.05)$ by the different level of furrow methods and mulch types (Table 2).

Higher biomass yield was recorded when convectional furrow irrigation method applied that gave 14.5 tone $\mathrm{ha}^{-1}$ and followed by alternative furrow irrigation method with the value of 13.26 tone ha $\mathrm{h}^{-1}$. The lowest biomass yield of maize was obtained from the treatment of fixed furrow irrigation method with the value of 12.28 tone $\mathrm{ha}^{-1}$.

In the other hand the effect of mulching was showed a significant difference among the different treatments. Plastic mulch was recorded were scored the highest biomass yield of maize with the value of 14.41 tone $^{-1}$ followed by alternative furrow irrigation method. Fixed furrow irrigation method was observed the lowest biomass yield of maize as compare the other treatments of mulch.

Different studies also revealed that different mulching condition and level affects aboveground and straw yield of maize. Even though irrigation water depth is reduced due to different irrigation water management methods like alternate and fixed furrow, the applied depth could be conserved due to the reduction of evaporation from soil surface by mulching. The conserved moisture content of soil in the root zone could enhance crop transpiration and nutrient uptake and transportation in the plant body. The straw yield decreased in the case of alternate and fixed furrow might be due to a reduction in photosynthesis in which chlorophyll is important. This may be due to the higher photosynthesis rate performed due to large biomass production, which most part of the biomass is straw.

According to Shamsi (2010), the effect of moisture stress reduces chlorophyll content, which leads to minimizing biomass production. Other researchers such as Guo et al. (2013) also reported similar results. Mo et al. (2017) reported that maize biomass was improved by $73.5 \%$ in black plastic mulch as compared with nonmulching condition. Similarly, Xu et al. (2015) reported that plastic mulching improves the accumulation of dry matter, leading to a significantly greater final biomass and an improvement of grain yield of maize by $15-26 \%$ both in the dry years. Moreover, Yaseen et al. (2014) revealed that maximum increase in biomass $(29.56 \%)$ and grain yield $(35.5 \%)$ were recorded on mulch and higher irrigation depth treatments. Many researchers such as Mulugeta and Kannan, (2015); Kedir, (2018) and Meskelu et al. (2018) have reported similar results in maize straw yield production. Application of plastic mulch increases crop yield through improving solar energy, water and fertility status of soil, reducing soil water loss and removing weeds (Bu et al., 2013).

\subsection{Water productivity}

The different types of furrow irrigation water management methods on maize have shown a significant $(p<0.05)$ influence on water productivity (Table 3). The results showed that the water productivity of maize was higher under alternate furrow irrigation method as compared with conventional and fixed furrow method. The highest water productivity $\left(1.75 \mathrm{~kg} / \mathrm{m}^{3}\right)$ was recorded at alternate furrow irrigation method and statically superior to both conventional and fixed furrow methods.

The minimum water productivity $\left(1.1 \mathrm{~kg} / \mathrm{m}^{3}\right)$ was observed at conventional furrow method and this was statistically inferior to both alternate and fixed furrow method during growing seasons (Table 2). The irrigation water application method of alternative furrow method $(50 \% \mathrm{ETc})$ was gave proportionally higher water productivity compared with conventional furrow $(100 \% \mathrm{ETc})$.

Different types of mulch highly significantly $(\mathrm{p}<0.05)$ influenced maize water productivity. The maximum water productivity $\left(1.54 \mathrm{~kg} / \mathrm{m}^{3}\right)$ was recorded at plastic mulching and statistically superior to no mulch. Plastic and straw mulch had statistically no significant difference. The minimum water productivity $\left(1.39 \mathrm{~kg} / \mathrm{m}^{3}\right) \mathrm{was}$ recorded at non-mulch condition was statistically inferior to both straw and plastic mulching.

The study of Kang et al (2000) indicated that AFI had better performance for increasing WUE and relative to alternate furrow irrigation resulted in significant reduction in Maize grain yield. Further, this might be due to moisture conservation by minimizing evaporation from the soil and alternately wetting all furrows and root zone during successive irrigation in case of plastic mulching under alternate furrow method. This leads to utilize much of the irrigation water for transpiration and nutrient uptake from the soil so that the amount of grain obtained per amount of irrigation water applied maximized under limited water condition (Panigrahi et al., 2011).

Different studies conducted on maize reveal water application methods in furrow irrigation and types of mulches affect water productivity of irrigated maize (Meskelu et al., 2018). They reported that yield reduction in 
AFI was not significant unlike FFI. Based on their findings (Nasri et al., 2010) concluded that alternate furrow irrigation as a way to save water in arid area where maize production relies heavily on repeated irrigation. Similarly, different mulching types lead to maximizing water productivity. Montazar and Kosari (2007) reported that water use efficiency of different crops including maize could be enhanced though mulching to conserve moisture in the soil for proper utilization by the plant. The conserved moisture content of soil in the root zone due to mulching could enhance crop transpiration and nutrient uptake and transportation in the plant body with limited available water.

Table 2. Effect of furrow methods and types of mulches on maize plant variables.

\begin{tabular}{lccccccc}
\hline Treatments & \multicolumn{9}{c}{ Mean Squares } & \multicolumn{1}{c}{} \\
\cline { 2 - 9 } & PH & CL & CD & SW & GY & BY & WP \\
\hline Furrow Method & & & & & & & \\
AFI & $198.22^{\mathrm{b}}$ & $15.7^{\mathrm{b}}$ & $4.3^{\mathrm{b}}$ & $294^{\mathrm{b}}$ & $4.81^{\mathrm{b}}$ & $13.26^{\mathrm{b}}$ & $1.75^{\mathrm{a}}$ \\
CFI & $209.11^{\mathrm{a}}$ & $16.6^{\mathrm{a}}$ & $4.5^{\mathrm{a}}$ & $322.8^{\mathrm{a}}$ & $5.7^{\mathrm{a}}$ & $14.5^{\mathrm{a}}$ & $1.1^{\mathrm{c}}$ \\
FFI & $194.2^{\mathrm{b}}$ & $15.1^{\mathrm{c}}$ & $4.1^{\mathrm{c}}$ & $286^{\mathrm{b}}$ & $4.33^{\mathrm{c}}$ & $12.38^{\mathrm{c}}$ & $1.5^{\mathrm{b}}$ \\
\hline LSD ( p=0.05) & 4.47 & 0.4 & 0.12 & 12.1 & 0.24 & 0.79 & 0.11 \\
\hline Mulching Type & & & & & & & \\
Straw mulch & $201^{\mathrm{b}}$ & $15.9^{\mathrm{b}}$ & $4.3^{\mathrm{b}}$ & $298.8^{\mathrm{b}}$ & $5.02^{\mathrm{b}}$ & $13.57^{\mathrm{b}}$ & $1.5^{\mathrm{a}}$ \\
Plastic Mulch & $212.11^{\mathrm{a}}$ & $16.5^{\mathrm{a}}$ & $4.6^{\mathrm{a}}$ & $322^{\mathrm{a}}$ & $5.27^{\mathrm{a}}$ & $14.41^{\mathrm{a}}$ & $1.54^{\mathrm{a}}$ \\
No mulch & $188.4^{\mathrm{c}}$ & $14.96^{\mathrm{c}}$ & $4^{\mathrm{c}}$ & $282^{\mathrm{c}}$ & $4.55^{\mathrm{c}}$ & $12.15^{\mathrm{c}}$ & $1.39^{\mathrm{b}}$ \\
\hline LSD (0.05) & 4.47 & 0.4 & 0.12 & 12.1 & 0.24 & 0.79 & 0.11 \\
CV & 2.3 & 2.5 & 3 & 4.8 & 5.3 & 6.1 & 7.6 \\
\hline
\end{tabular}

*Means followed by different letters in a column differ significantly and those followed by the same letter are not significantly different at $\mathrm{p}<0.05$ level of significance. $\mathrm{PH}=$ plant height $(\mathrm{cm}), \mathrm{CL}=$ cob length $(\mathrm{cm}), \mathrm{CD}=$ cob diameter $(\mathrm{cm}), \mathrm{SW}=$ seed weight $(\mathrm{g}), \mathrm{GY}=$ grain yield (tone $/ \mathrm{ha}), \mathrm{BY}=$ biomass yield (tone $/ \mathrm{ha})$ and $\mathrm{WP}=$ water productivity $\left(\mathrm{kg} / \mathrm{m}^{3}\right)$

\subsection{Water productivity versus grain yield}

The results obtained in this research showed that maize grain yield in Figure 2 drawn, convectional furrow irrigation method with plastic mulch recorded the highest yield followed by convectional furrow irrigation method. In theater hand, Alternative furrow irrigation method with no mulch and fixed furrow irrigation method with no mulch was showed the lowest maize grain yield respectively.

The highest water productivity was recorded from alternative furrow irrigation method with plastic mulch followed alternative furrow irrigation method with straw mulch and the lowest water productivity was obtained from convectional furrow irrigation method with straw mulch and convectional furrow irrigation method with no mulch respectively. The figure shows that, as mulching practice used the maize grain yield and water productivity increased.

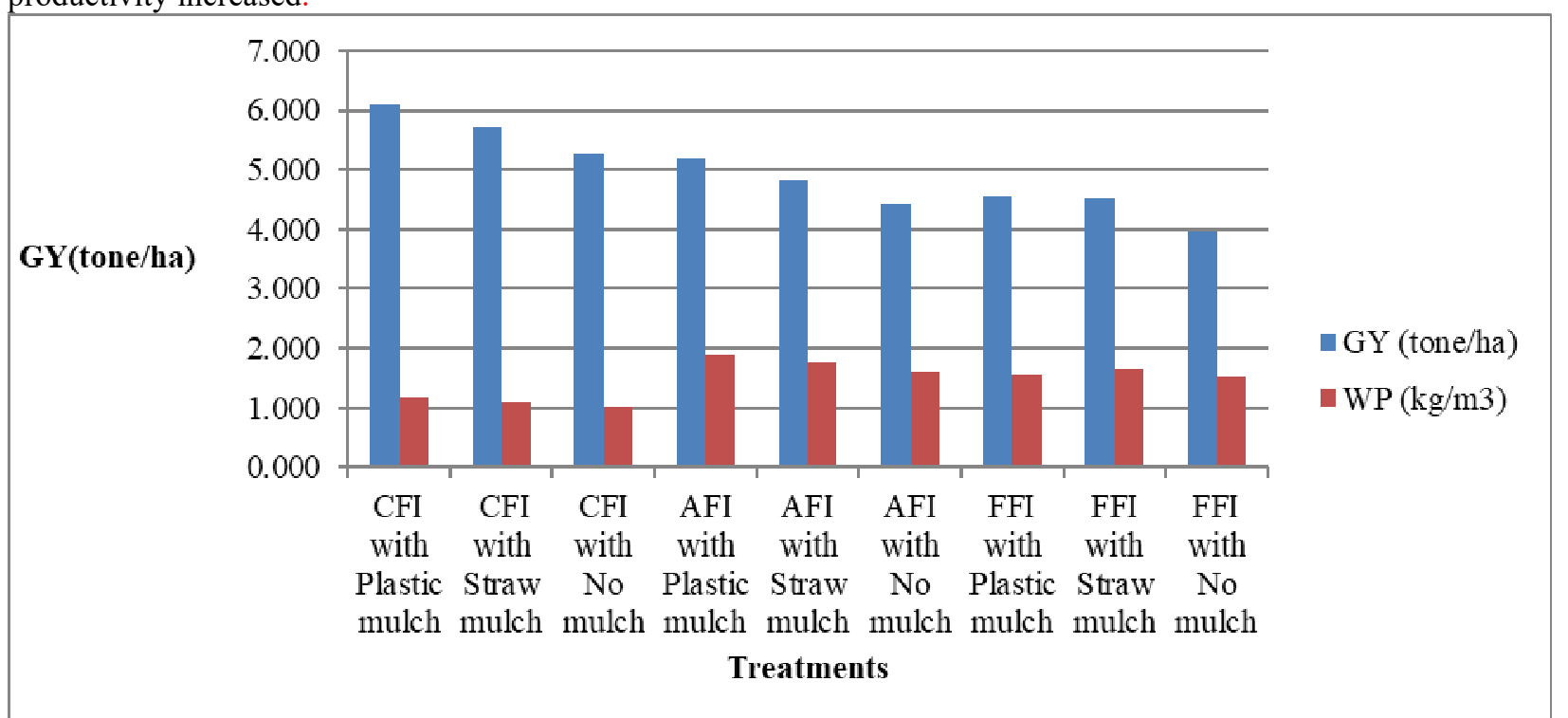

Figure 2. Maize grain yield versus water productivity of treatments

\section{Conclusions}

From the results of the study, the following points can be concluded. Generally, mulching showed 
significant effect on water use efficiency and agronomic parameters. According to the findings of this experiment, the highest maize grain yield production and water productivity was obtained when a conventional furrow irrigation method or an alternative furrow irrigation method was used. Moreover, application of plastic mulch leads to significantly higher yield and yield components of maize than straw mulch or with no mulching condition. In this experiment application of mulch played a greater role in minimizing evapotranspiration. The study area water is a limiting factor and alternate furrow irrigation method could be practiced with plastic mulch for improving maize grain yield and water productivity.

\section{Conflict of interests}

The authors have not declared any conflict of interests.

\section{Acknowledgments}

The authors are grateful to Ethiopian Institute of Agricultural Research, Natural Resource Management Research Directorate for giving funds for the experiment. They are also great thanks to Mehoni Agricultural Research Center, Natural Resource Management Research Process for supporting during the field experiment. They are also great thankful to Birhane Hailu, Mogos Meresa and Abraha Tegen for their support and technical assistance in the field experimentation.

\section{References}

Ali, R. and Raouf, S. S. 2012. Effects of rates and nitrogen application timing on yield, agronomic characteristics and nitrogen use efficiency in corn. International Journal of Agriculture and Crop Sciences, 9: 534-539.

Awal, M.A. and Khan, M.A.H. 2000. Mulch induced eco-physiological growth and yield of maize. Pak J Biol Sci, 3: 61-64.

Biswas, K.A.1997.Water development and environment. In: Biswas,A.K.(ed).Water resources: environmental planning, management, and development. Tata McGraw-Hill.New Delhi, India.

$\mathrm{Bu}$ YS, Shao HL, Wang JC (2002). Effects of different mulch materials on corn seeding growth and soil nutrients contents and distributions. J. Soil Water Conserv. 16: 4042.

Bu, L.D., Liu, J.J., Zhu, L., Luo, S.S., Chen, X.P., Li, S.Q., Robert, L.H., Zhao, Y. 2013. The effects of mulching on maize growth, yield and water use in a semi-arid region.Agr. Water Manage, 123, 71-78.

Dehkordi, N. and Farhadi, R.2016 Mulch Treatment with Mulch Planter and its Effects on Maize Production. Agric Conspec Sci 80: 247-252.

FAO (Food and Agriculture Organization of the United Nations). 2011. The State of the World's Land and Water Resources for Food and Agriculture. Managing Systems at Risk. FAO Rome.

Farooq, M., Wahid, A., Kobayashi, N., Fujita, D. and Basra, S. M. A. 2009. Plant drought stress: effects, mechanisms and management. Agron. Sustain. Dev. 29: 185-212

Guo, R., Hao, W.P., Gong, D.Z., Zhong, X.L. and Gu, F.X. 2013. Effects of water stress on germination and growth of wheat, photosynthetic efficiency and accumulation of metabolites. In Soil Processes and Current Trends in Quality Assessment. In Tech.

Jehan B.S., Ahmed, M., Tariq, H., Akbar and Shafi, M. 2007. Response of maize to planting methods. Asian research Publishing Network, 1(3).

Kang, S.Z., Liang, Y. P and Zhang, J., 2000. Alternate furrow irrigation for maize production in an arid area. Agricultural Water Management, 45: 267-274.

Katherine MJ, David WM, Wayne E (2006). Weed control options for strawberries on North Carolina State University. (Available at http://www.ces.ncsu.edu/ depts/ hort/hil /hil- 205-b Cited 15 Jun 2012).

Kedir J (2018). Effect of water application methods in furrow irrigation along with different types of mulches on yield and water productivity of maize ( zea mays 1.) at Hawassa, Ethiopia.

Kumar D, Singh R, Gadekar H, Patnaik US (2003). Effect of different mulches on moisture conservation and productivity of rainfed turmeric. Indian Journal of Soil Conservation 31 (1):41-44

Li R, Hou X, Wang X, Jia Z, Han Q (2016). Research progress on the dual-mulching of ridge and furrow technology in dry farming regions of northern China. Chinese Journal of Applied Ecology 27:1314-1322. doi: 10.13287/j.1001-9332.201604.038.

Li XY, Gong JD, Gao QZ, Li FR (2001). Incorporation of ridge and furrow method of rainfall harvesting with mulching for crop production under semiarid conditions. Agric. Water Manage. 50: 173-183.

MehARC ( Mehoni Agricultural Research Center) 2015., Annual research report of Land and water research process, Maichew, Tigray, Ethiopia.

Meskelu, E., Tesfaye, H., Debebe, A. and Mohammed, M. 2018. Integrated Effect of Mulching andmFurrow Methods on Maize Yield and Water Productivity at Koka, Ethiopia. Irrigation Drainage Sys Eng, 10:4172/2168-9768.

Mo, F., Wang, J.Y., Li, F.M., Nguluu, S.N., Ren, H.X. 2017.Yield-phenology relations and water use efficiency 
of maize (Zea mays L.). In ridge-furrow mulching system in semiarid east African Plateau. Scientific Reports, 7: 3260 .

Montazar, A, Kosari, H. 2007. Water productivity analysis of some irrigated crops in Iran. In Proceeding of the international conference of water saving in Mediterranean agriculture and future needs. Valenzano, 56: 109120

Mulugeta and Kannan. 2015. Effect of Deficit Irrigation on Maize under Conventional, Fixed and Alternate Furrow Irrigation Systems at Melkassa, Ethiopia. International Journal of Engineering Research \& Technology, (IJERT) ISSN: 2278-0181:pp-pp.

Nagalakshmi S, Palanisamy D, Eswaran S and Sreenarayanan V V 2002 Influence of plastic mulching on chilli yield and economics. South Indian Horticulture 50 (1-3) : 262-265.

Nasri, M. Khalatbari, M. Farahani, H.A. 2010. The effect of alternate furrow irrigation under different nutritional element supplies on some agronomic traits and seed qualitative parameters in corn (Zea mays L.). JCO 1: 17-23.

Osman, Y., Oner, C., Demet, U. and Hasan, B. 2001. Irrigation scheduling of Drip-irrigated Tomato using A pan evaporation, Turkey Journal of Agriculture, 26(2002)171-178.

Panigrahi, P. Sahu, N.N, Pradhan, S. 2011. Evaluating partial root-zone irrigation and mulching in okra (Abelmoschus esculentus L.) under a sub-humid tropical climate. JARTS, 112: 169-175

Ramakrishna, A., H.M. Tam, S.P. Wani and T.D. Long, 2006. Effect of mulch on soil temperature, moisture, weeds infestation and yield of groundnut in Vietnam. Field crop66 Research, 95(2/3): 115-125. http://www.aginternet.network.net.Accessed on: September28/2008.

Ren X, Cai T, Chen X, Zhang P, Jia Z (2016). Effect of rainfall concentration with different ridge widths on winter wheat production under semiarid climate. European Journal of Agronomy 77:20: 27.doi: 10.1016/j.eja.2016.03.008.

Saroa GS, Lal R (2003). Soil restorative effects of mulching on aggregation and carbon sequestration in a Miamian soil in Central Ohio. Land Degrad. Dev. 14: 481-493.

Singh, G., Joshi, V.K., Chandra, S, Bhatnagar, A., Dass, A. 2016. Spring maize (Zea mays L.) response to different crop establishment and moisture management practices in north-west plains of India. ROC 17.

Shamsi, K., Petrosyan, M., Noor-Mohammadi, G. and Haghparast, R. 2010. The role of water deficit stress and water use efficiency on bread wheat cultivars. Journal of Applied Biosciences. 35: 2325- 2331.

Wang HL, Zhang XC, Song SY, Ma YF, Yu HF, Liu YL (2011). Effects of whole field-surface plastic mulching and planting in furrow on soil temperature, soil moisture, and corn yield in arid area of Gansu Province, Northwest China. J. Applied Ecol. 22: 2609-2614.

Yaseen, R. Shafi, J. Ahmad, W. Rana, M.S, Salim, M. 2014. Effect of deficit irrigation and mulch on soil physical properties, growth and yield of maize. Environ Ecol Res, 2: 122-137.

Zhang DQ, Liao YC, Jia ZK (2005). Research advances and prospects of film mulching in arid and semi-arid areas. Agric. Res. Arid Areas 23: 208-213.

Zhang P, Wei T, Cai T, Ali S, Han Q, Ren X, Jia Z (2017). Plastic-film mulching for enhanced water-use efficiency and economic returns from maize fields in semiarid China. Frontiers in Plant Science 8:512. 